\title{
Does the Mediterranean way of life affect death rates from cardio- vascular diseases in Croatia?
}

\author{
Rosanda Mulić*, \\ Iris Jerončić Tomić \\ University of Split School of \\ Medicine, Split, Croatia
}

\author{
KEYWORDS: cardiovascular diseases, Croatia, lifestyle. \\ CITATION: Cardiol Croat. 2017;12(9-10):390. | https://doi.org/10.15836/ccar2017.390
}

*ADDRESS FOR CORRESPONDENCE: Rosanda Mulić, Medicinski fakultet Sveučlišta u Splitu, Šoltanska 2, HR-21000 Split, Croatia. / Phone: +385-91-4433-810 / E-mail: rosanda.mulic@unist.hr

ORCID: Rosanda Mulić http://orcid.org/0000-0002-3758-5618 • Iris Jerončić Tomić http://orcid.org/0000-0002-1510-4000

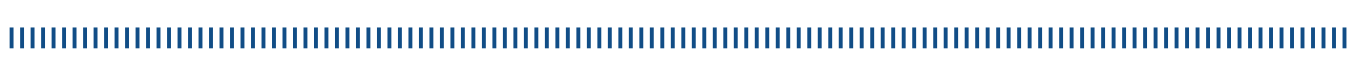

Cardiovascular diseases (CVD) are the leading cause of death in Croatia with the highest mortality rate among European Mediterranean countries, with significant regional differences. ${ }^{1-3}$ The hypothesis is that technological advances and transition changes have diminished the impact of Mediterranean lifestyle in Croatia, a country that has one third of its territory and one quarter of the population living in the Mediterranean area. As a possible indicator of the Mediterranean lifestyle we used standardized death rates of CVD per 100,000 inhabitants and compared these to the rates in some other Mediterranean countries. Furthermore, we also did an in-country comparison of the counties/regions. We used the data from Eurostat and from Croatian Health Statistics Yearbook. The EU-28's standardized death rate for diseases of the circulatory system was 383 deaths per 100,000 inhabitants in 2013, with the rate for men being some 1.4 times higher than that for women. During 2014, among Mediterranean countries France had the lowest death rate from CVD (49.3 per 100,000 inhabitants), and Croatia the highest (306.5). Among Croatian counties, the lowest rates have been recorded in coastal areas (Šibenik-Knin County 264.3) and the highest among continental counties - such as Virovitica-Podravina County $(475.4 / 100,000)$. In the $0-64$ age group, rates range from as high as 48.5 in the continental KrapinaZagorje County down to 16.3 in the littoral Šibenik-Knin County. In Croatia standardized death rates for CVD were systematically higher for men than for women. Over the last ten years we have seen a continuing downward trend in mortality caused by CVD, which is more pronounced for cerebrovascular diseases, than for ischemic heart disease and especially for the 0-64 age group, but CVD are still the major cause of mortality and morbidity. We concluded that in the coastal counties the mortality rate of CVD is lower than in the continental, and the probable cause is still the Mediterranean way of life in the coastal area. Public health needs to invest more efforts in preventing cardiovascular diseases in Croatia.
RECEIVED:

September 1, 2017

ACCEPTED:

September 26, 2017

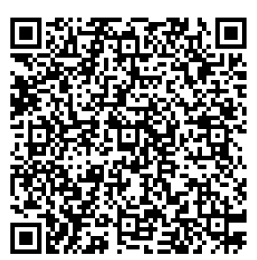

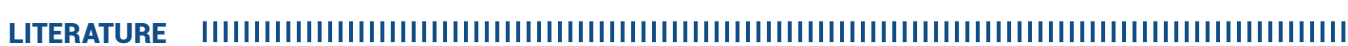

1. Kardiovaskularne bolesti u Republici Hrvatskoj. Hrvatski zavod za javno zdravstvo, Ministarstvo zdravlja Republike Hrvatske, Zagreb, 2013. Available at: https://www.hzjz.hr/wp-content/uploads/2013/11/KVBbilten_2011-10-5-2013-3.pdf (31. 8. 2017).

2. Kern J, Polasek O, Milanović SM, Dzakula A, Fister K, Strnad M, et al. Regional pattern of cardiovascular risk burden in Croatia. Coll Antropol. 2009 Apr;33 Suppl 1:11-7. PubMed: https://www.ncbi.nlm.nih.gov/pubmed/19563140

3. Kralj V, Brkić Biloš I. Morbidity and mortality from cardiovascular diseases. Cardiol Croat. 2013;8(10-11):373-378. https://doi.org/10.15836/ccar.2013.373 